\title{
Semiotico-translation-theoretical reverberations revisited
}

\author{
Ritva Hartama-Heinonen \\ Swedish Translation Studies, Nordica \\ Department of Finnish, Finno-Ugrian and Scandinavian Studies \\ Unioninkatu 40, 00014 University of Helsinki, Finland \\ e-mail: ritva.hartama-heinonen@helsinki.fi
}

\begin{abstract}
This article examines translating and translations primarily from a sem(e)iotic viewpoint. The focus is, on the one hand, on a semiotic re-reading of certain translationtheoretical suggestions (such as the idea of translation being an inherently semiotic category), and on the other hand, on a translation-theoretical re-reading of certain semiotic suggestions (such as what signs can be used for representing). Other proposals that receive a revisiting discussion include, for instance, Roman Jakobson's translation typology and Umberto Eco's notion of semiotics as a theory of the lie. The approach adopted in the present article advocates a serious re-reading and attitude, but even more, a literal reading and sometimes, a less serious attitude as well.
\end{abstract}

Within the fields of semiotics and translation studies we encounter ideas that are considered to be perhaps so self-evident that the discussion and application of them remains on the level of referring and asserting and has a tendency to be mere recycling. One after another, scholars appear to seek support from the very same views and passages, as if these quotations and proposals with their diverse ways to approach the given phenomena had already become axioms with no need for further enhancement, refining, or proliferation through revisiting, reinvestigating, and rejustifying. This article examines some translation-relevant suggestions and semiotic vantage points, attempts to reanalyse these and to focus on what might happen when we do not take these suggestions and vantage points as given. Instead, let us consider some of these proposals seriously, sometimes literally, sometimes even to the extreme, and some even less than seriously. The aim is to shed light in a truly pragmatistic sense on both the theoretical and the practical consequences of these 
knowledge claims, such as that translation is a thoroughly semiotic category, that translation is a textual replacement, or that to translate is to lie.

\section{No kidding}

Translation and Interpreting (T/I) Studies is particularly suitable as a theoretical discipline for a semiotically oriented investigator. For those interested in translational and translatorial questions, T/I Studies offers a kind of a test laboratory, providing an opportunity to experiment with, to observe, and to practise varied sign-theoretical ideas, views, and approaches. Most essentially, these include the idea of ubiquitous semiosis that is an inherent melting pot of such phenomena as representation, mediation, translation, interpretation, understanding, and the growth of meaning, etc. All of these are crucial with respect to interlingual translation, or to translation proper, as Roman Jakobson (1896-1982) called this type of interpretation of verbal signs. But these phenomena are certainly highly relevant even in relation to non-verbal signs and sign systems and to the other two Jakobsonian modes of translating, the intralingual and the intersemiotic one (Jakobson 1966[1959]: 233).

Whereas for a researcher, the aforementioned laboratory is metaphorically speaking more or less a laboratory of the mind and therefore not a realm of actual translating actions and of authentic translation practice, the opportunity is seldom seized to engage temporarily in some playfulness and to embark on inspiring thought experiments, be they semiotic or other types. This seldom occurs, even though the field of translation (and thereby, our object of study) is by definition a field of creation and creativity. In other words, in this respect, research may benefit from increased flexibility, more imagination and relaxed non-seriousness. Some support for this claim can be found in the statements by Theo Hermans, who has pointed out that research on translation very easily adopts "the traditional construction of translation as a derivative type of manufacture under cramped conditions" (2006: ix). According to Hermans, adopting this assumption, for instance, can result in approaching translation norms as an issue of behavioural constraints, not as solving problems through imaginative manipulation and selection as strategic tools, as one might expect an alternative angle of vision to be.

Another reason for this lack of a thought-experimental orientation to translation studies might be that today, some translation researchers and scholars themselves have earned degrees in T/I Studies or in closely related 
subjects. Furthermore, many researchers in translation are also practising translators and interpreters and have mastered the daily work of a translator, or, as translation teachers, have close contacts with practitioners in the field. As a consequence, it might be less tempting to study the practice of translation (translation processes), the outcome of this processual practice (products, or translations), or the process- and product-related situations (contexts), as well as those involved (agents), and to do this from the outside, theoretically, hypothetically, and virtually, when one can instead approach these from within, and not speculatively but concretely and empirically, as an active member of the translating community and as belonging to those who live on translation and moreover, in translation. In short, the organic link between the theory of translation, or translation research, and the practice of translation is strong and inevitably natural, and this is a circumstance that certainly favours empirical approaches to translation.

Even the age-old view of the translator as a servant or as a copier may have some impact here, as has the fact that translating is often discussed in a narrow sense, in terms of meaning preservation (equivalence, sameness, semantic adequacy, etc.). Yet the target sign, the translated text, cannot be the same as the source sign, the translating text, and this is due to the unavoidable spatiotemporal changes and moreover, is imposed by the four parameters listed above. Besides, any other conclusion would defy logic. Given this, the translator is somehow obliged to ignore or betray his or her traditional professional duty, since the preserver role of the translator seems to be hopeless from the very beginning. In any event, the translator is a betrayer only where the conception of sameness is prevailing or when sameness is required. Sameness is thus primarily an intraprofessional, conceptual illusion, which is shared by those within translation studies, and difference instead dominates in 'the reality', that is, in the practice of translation. And even where research has rejected the idea of sameness or any other textual-normative tendency or flavour, and has been satisfied with being able to describe (from Latin describere, 'to copy off') the target-centred aspects of translations and translating, normativeness is still present in descriptive translation studies. Indeed, normativeness persists as if there were a hidden agenda, since the results of the descriptive orientation run the risk of creating, or transforming themselves into, a different translational and translatorial indicator and behavioural norm and constraint.

Finally, translating has been approached as an act of balancing between the diverse degrees of fidelity and loyalty, even though the more far-reaching anti- 
imitative ideas of re-writing, re-creation, and (r)evolutionary strategic rethinking are relatively familiar concepts. Yet these anti-imitative ideas have been presented primarily concerning the field of literary translation and are reflected, for example, in such approaches as the cannibalistic translation, the carnivalistic translation, and the feminist translation. ${ }^{1}$ The translators of nonfiction somehow appear to be more restricted, perhaps due to the deep-rooted, traditional controversy and juxtaposition of faithful and free translation. That in one way or another, echoes the word-sense distinction and the polarity between source- or target-orientedness, or to mention some other related powerful dichotomies and guiding strategic principles, alienating/naturalizing; formal/ dynamic or functional; semantic/communicative; overt/covert; adequate/ acceptable; documentary/instrumental; and foreignizing/domesticating.

In short, this being the state of the play, we can reflect on the extent to which genuine freedom actually exists in academic research. This includes the latitude for researchers, freedom of thought and, further, whether there is currently any need for these features. Perhaps, to the contrary, these aspects of academic freedom may be something that, things being as they are, only hamper inquiry and scholarly thinking and progress. In fact, at the moment, this constitutes a possible conclusion.

1 The history of translation is replete with diverse principles, one of the most striking being that of Abraham Cowley (1618-1667), proclaimed in the preface to the Pindarique Odes (1656; as cited in Bassnett 1991: 59): "I have taken, left out and added what I please". The national histories of translation contain, correspondingly, rather extreme approaches to translating. An example from Finland could be the introduction to the translation into Finnish of Euripides' play Heracles (Saarikoski/Euripides, Herakles, Otava 1967) written by Pentti Saarikoski (1937-1983), author, poet, and literary translator. Saarikoski's arguments for his high-handedness (Saarikoski 1967: 7) are intriguing: he did not try to imitate the metres of Euripides, because the result would have been a text that is neither suitable for the Finnish actor nor pleasing to the Finnish reader; he had omitted passages which he had considered to be uninteresting or boring for a modern audience, or otherwise useless; and if he had found a more telling expression, he had employed it without any particular respect for the original writer. Whereas the purpose of the translation was, for Cowley, somewhat source-centred, that is, to convey not what was said but how it was said, the aim in Saarikoski's translation was rather target-centred, that is, to produce a text that both readers and theatre-goers would find interesting. According to Saarikoski, his translation pays tribute to Euripides. 


\section{Living in translation}

In spite of the rapid development within translation research today and the increasing references to what have been termed 'the turns' of this field of knowledge, the changes of course and perspective proceed slowly, yet steadily. A rather conservative, ambivalent, if not reluctant, way of thinking and a possible impediment to the progress of semiotics is mirrored in what could be referred to as diverse gatekeeper attitudes towards what translation entails.

Despite increasing signs of rapprochement between semiotics and translation studies, the nature of translation and subsequently, how it influences research, currently seem to constitute a watershed. A frequently quoted statement concerning the relation of translation to semiotics is that by the translation scholar Susan Bassnett (1991[1980]: 13; her italics): "Although translation has a central core of linguistic activity, it belongs most properly to semiotics, the science that studies sign systems or structures, sign processes and sign functions." Even within semiotics, we can find corresponding views that advocate translation as an inherently and thoroughly semiotic category. Such a position is adopted in the following passage, which was voiced by Susan Petrilli (2001: 278-279; her italics) when stating that translating and translatability "are prerogatives of semiosis and of the sign. Translation, therefore, is a phenomenon of sign reality and as such it is the object of study of semiotics". Now that ten or thirty years have passed since these two viewpoints were originally articulated, it is still quite impossible to find anything that is explicitly ranked and unanimously acknowledged as semiotic translation studies within translation studies, or as semiotics of translation within theoretical or applied semiotics. Nevertheless, we can hardly say that positions of this kind would consist of empty words. On the contrary, they must be formulated through deeper reflection by their presenters. However, in the research of their interpreters, standpoints such as these have not always become the guidelines of projects, nor have they been translated into action or put to any deepergoing trial, but are simply repeated and remain as well-known asserting tenets. To some, these are nothing but platitudes.

This resistance to adopting proposals is actually what the translation scholar Mona Baker (1998: xvii) refers to in passing when she discusses translation types: the investigation into the history of translation "reveals how narrow and restrictive we have been in defining our object of study, even with the most flexible of definitions". Referring particularly to the intralingual and intersemiotic modes of translation, Baker concludes, which is surprising, at least 
from a translation semiotician's point of view, that even though the possibility of these modes is recognised, for instance, through the typology of Jakobson, "we do not make any genuine use of such classifications in our research".

After reading this positive approach to the classification by Jakobson, linguist and semiotician, as well as the advocating of categorisations of this type that point to a broader conception of translation that ought to be drawn on to a greater extent, we can turn to a more critical stance expressed by Aline Remael. The following quotation in part conveys the lack of cross-disciplinary dialogue in general as well as the lack of the dialogue between the scholars of semiotics and translation studies concerning the work of Jakobson and his followers and interpreters (on references to Jakobson within semiotics and translation studies, see Sütiste 2008). ${ }^{3}$ In addition, it shows a lack of appreciation for the achievements of those who have, since the 1980s or 1990s, embraced a semiotic approach to translation:

The 21st century may well see the advent of the "audiovisual turn" in $T$ [ranslation] $S$ [tudies]. Initially, TS limited itself to bible translation and literary translation. Only later did TL research extend to translation of other text types, although it remained focused on translation of verbal texts in one language into verbal texts in another language, or, in Jakobson's terms, interlingual translation or translation proper (Jakobson 1959/2009). Jakobson also coined intralingual translation (or rewording) and intersemiotic translation (or transmutation) to refer to related fields, but his very terminology relegated the terms to translation's periphery. The current inundation of text production modes and the ubiquity of image and/or sound in texts have made it virtually impossible to adhere to such a limited concept of translation. (Remael 2010: 15; emphases in original)

Those semioticians who are interested in the phenomenon of translation in fact have long examined the concept of translation in different spatio-temporal contexts, and have advocated a natural, broad definition of translation for them. This definition, derived from the views of Jakobson, as well as from those of many other semioticians before and after him, can be crystallized in the formulation translation is translation and beyond (Hartama-Heinonen 2008:

2 Likewise, it is surprising that Baker states (1998: xvii, written in 1997) that she knows "of no research that looks specifically at the phenomena of intralingual or intersemiotic translation".

3 The work and impact of Jakobson seems to be a current object of re-evaluation (see Torop 2008b), and his intersemiotic type of translation receives re-interpretations (see, for instance, Torop 2000, 2008c or Hartama-Heinonen 2008: 55-66, 268-269). 
61). However, as demonstrated above, advocating does not necessarily imply accepting. Not everyone is ready to accept any definition of translation, ${ }^{4}$ nor would merely any definition reach all those involved and interested, as we can also deduce from the above.

The semiotic approach to translation first leads us to the sphere of texts and discourses (and this is the world that Remael describes above) that presuppose the co-existence, interaction, and even the confrontation of different semiotic systems and signifying practices. These systems, which reach beyond linguistic boundaries, manifest themselves in varying codes and combinations. These can be perceived in the interplay between word, (moving) image, or sound (or the verbal, written or spoken; the kinesic; the visual; or the vocal/auditory) - and in cases where the diversity of signifying systems, intermediality, and the intersemiosic interaction is highlighted, as in comics, multimedia, plays, songs, audiovisual TV and film material, etc., and consequently, in their translations.

Secondly, a sign-theoretical approach can focus our attention on a more extensive milieu, that is, on the immediate socio-cultural sign environment, and even further, on the whole semiosphere. Again, the conventional conception of translation as an event that occurs between natural languages (translation conceived as interlingual or language-mediated communication) receives a new facet. Or, as Charles Sanders Peirce (1839-1914) explained the life of a symbol (CP 2.302, c. 1895): "In use and in experience, its meaning grows". Such an extension of the use of the symbol and term 'translation' has been advocated and discussed, among others, by Peeter Torop (for example, see Torop 2001, 2002 and the other Torop references). To Torop, the translation process presupposes not only a translating mind, but translation is a process that takes place even "within language, culture, and society" (Torop 2008c: 377; cf. 2008a: 228). As Torop observes, within cultural semiotics, it is considered to be natural "to say that culture is translation, and also that translation is culture.

4 Not to know is one thing, to know another. As a case of knowing and deliberately rejecting, I would like to refer to Peter Newmark (1916-2011) and to his statement in his Paragraphs on Translation (1993: x): "As an excuse, I can always have recourse to Ramon [sic] Jakobson's and George Steiner's thesis that virtually any mental process is translation, though I do not personally subscribe to this thesis." What appears to have been unknown to Newmark is that even Juri Lotman (1922-1993) used translation in a non-translationtechnical sense when stating (where else but in the currently often quoted passage) that "translation is the elementary act of thinking" (Lotman 1990: 143). 
[...] translation activity is also an activity that explains the mechanisms of culture" (Torop 2002: 603).

And thirdly, according to the widest semiotic interpretation, not only translators and translation scholars in the strict (interlingual) sense of the word live on translation and in translation. Indeed, living in translation concerns all of us. While every translation involves a sign process (with human translating being sign processing), every sign involves a translation process, at least from the Peircean perspective. Or, as Peirce asserts, "But a sign is not a sign unless it translates itself into another sign in which it is more fully developed" (CP $5.594,1903)$. Life, when approached from this vantage point, is manifested as a chain or flow of translations, or as an unlimited and ubiquitous process of translation, also known as semiosis, and we all turn into translators. Yet if we take this very idea of translation to the extreme to see the possible consequences (and it is this pragmatistic aspect that I want to emphasize here as well as the direction that I attempt to promote with my article), there is, as a matter of fact, no actual translatorial in-betweenness (no translator-mediated communication). The above quotation attests to the claim that in a Peircean world, in this universe of signs, signs translate themselves.

\section{Sign translation, or representing, lying, substituting, and replacing}

The present article has thus far provided a point of departure and constructed a rather big picture of the semiotico-translation-theoretical objective and the frame of discourse. In the following, the original purpose of revisiting earlier semiotic and translation-theoretical proposals is continued, while the focus is shifted to more detailed features of signs. I consider this to be a justified and expected line of approach: surrounded by competing and contradictory views, we should probe them in a pragmatistic vein to be able to grasp their potential.

Hence as semioticians and/or as translation scholars, if we are convinced that translation as both a product and a process is a matter of semiotics, we need not only to assert this view in our inquiry, but we need to live up to this conviction, and to investigate actively the inherent implications and consequences such an approach entails, as well as the proposed semiotic way of life that it may in general encompass. Peirce himself was a case in point as to this pragmatistic attitude and, furthermore, a living proof of what dedication to the 
semiotic cause can imply. In 1908 at the age of 69, Peirce (PW: 85-86) stated that since the day that he began to read Whately's Logic, which was when he was twelve or thirteen years old, "it has never been in [his] power to study anything $[\ldots]$, except as a study of semeiotic". For Peirce, semeiotic, the study and theory of signs and semiosis, or dynamic sign action and meaningful sign interpretation, became a lifelong vision, commitment, and duty. Devotion of this kind may be necessary for any philosopher who wants to practise his or her philosophy. And this is what Peirce definitely did. When he put his semeiotic mission into practice, Peirce lived out his approach and beliefs; today, such fervour and ambition is probably exceptional. ${ }^{5}$

At first glance, translation can be reduced to an issue of language. Or, as the translation scholars Eugene A. Nida (1914-2011) and Charles R. Taber (1928-2007) expressed this (1982[1969]: 4), thereby foregrounding their trust in the nearly all-embracing power of translating: "Anything that can be said in one language can be said in another, unless the form is an essential element of the message". This maxim finds a parallel in the ideas put forward by the linguist and semiotician Louis Hjelmslev (1899-1965), but here it is the language that is nearly omnipotent:

In practice, a language is a semiotic into which all other semiotics may be translated - both all other languages, and all other conceivable semiotic structures. This translatability rests on the fact that languages, and they alone, are in a position to form any purport whatsoever; in a language, and only in a language, we can "work over the inexpressible until it is expressed." (Hjelmslev 1969 [1961]: 109)

While verbal signs appear to be something that we start from in interlingual translating, they are certainly not all that counts, at least not today. Within translation studies, it has become gradually more apparent as well as wellestablished that the verbal, language and linguistics, is not sufficient in our increasingly multimodal age. This is revealed, for instance, in the following prediction as to how the translator profession will develop, followed by the unavoidable conclusion and consequence for translation research: "[ $[.$.$] most$ of the future documents to be translated will be not only increasingly

5 For support for the latter claim, see Klemola 2004: 17-23. Timo Klemola discusses the importance of practising philosophy instead of theorizing, and argues that modern academic philosophy mainly consists of theoretical discourse and tends to ignore the possibility of philosophy as a way of life and due to the lack of this conscious exercise, is estranged from both practice and life. 
multisemiotic, but will also include more and more different media. It is time to train researchers beyond the traditional 'textual' paradigm" (Gambier 2009: 24). Within semiotics, this beyondness is evident and inherent. According to Els Wouters (1997; my emphases), semiotics explores "the larger contexts of signs" and the direction of the disciplinary evolution reaches "towards a global semiotics that envisages an understanding of signs in human behaviour and in nature in general. In this pansemiotic view, the emphasis will be on the sign outside linguistics" ${ }^{6}$

Semiotically speaking, translation approached as sign production means sign translation, or sign-mediated communication. The translating sign stands for something, with the translated sign standing for this translating sign. Proceeding from one sign to another sign - producing a sign out of a sign through translation - refers by definition to intersemiotic activity, a process between signs, and this concerns all types of signs and sign uses. In addition, translation can be described as an abductive truth-seeking action; paradoxically however, to translate also means to lie (for further, see Hartama-Heinonen 2008 and 2009). This holds true if we follow Umberto Eco's conception of the scope of semiotics: to study whatever there is that can be interpreted as a sign or can act as a substitution and furthermore, and this is the all-inclusive object of semiotic study, all that could be used for lying (Eco 1979: 7). This very idea of semiotics, which is what Eco refers to as a theory of the lie, is an excellent argument for the claim that the versatile phenomena of translations and translating belong to semiotics. For translating is in essence no more than the production of representing illusions, translated texts that endeavour to take the place of, replace, their original versions, yet being themselves merely representations of representations. As a sign, the translation stands for, refers to, represents, and signifies the original text and primary sign, though without being that text and that sign.

The aforementioned Eco-derived semiotic ideas of substituting and lying (and then the semiotically relevant, subsequent questions of whether a translation as a sign stands for the source text or whether it counts as the primary text) are in principle found within translation research. As we have seen, however, there are semiotic impacts in translation-theoretical literature, impacts that, for some reason, have not grown into a full-blown semiotics. It may be that these impacts are purely coincidental, having nothing to do with

6 See Wouters, Els 1997. Sign. In: Östman, Jan-Ola; Verschueren, Jef (eds.), Handbook of Pragmatics Online. Available at: www.benjamins.com/online/hop. 
semiotics proper, such that in the end, the interpretation of there being something semiotic is only in the eye of the beholder.

Whatever the case, the definition of translation offered by Petrus Danielus Huetius (1630-1721) deserves mention because in my interpretation, it draws on overtly semiotic thinking in its formulation: a translation is "a text written in a well-known language which refers to, and represents a text in a language which is not as well known" (Huetius 1992[1683]: 86; my emphases). Another intriguing fact, however, is André Lefevere's (1945-1996) close reading of this passage (1992: 1) and the way he addresses the questions based on the idea of representation that turn into questions of language, culture, power, ideology, and patronage. For example, there is the question whether a foreign text should be represented in another culture. Another issue regards who selects what is to be represented and who makes this representation. The third question concerns how the target culture receivers know that a text is properly represented. Finally, the problem is determining the reason for producing these referring-to texts instead of simply writing original ones. None of these questions and issues arises from the semiotic in the definition (namely, aliquid stat pro aliquo), yet they are all no doubt central to translation theory even today.

The evolution of the following translation definition proposed by Jenny Williams and Andrew Chesterman (2002: 1; my emphasis) is also intriguing: "a translation is a text in one language which is produced on the basis of a text in another language for a particular purpose." This was first slightly redefined in 2003 (Chesterman 2003) and the italicized passage was changed to counts as another text which is reminiscent of the semiotics-related aspect of lying. Subsequently, several years later, it was changed to a more explicitly semiotically oriented wording represents $a$ text. As in the definitions of translation in general, even here we see how the choice of expression alters the perspective and creates varying interpretations, semiotic but also less semiotic. (See also, Hartama-Heinonen 2008: 51 fn. 1, 2008: 70-71 fn. 1.)

Instead of substitution we could adopt the designation replacement. A semiotically oriented manifestation of the idea of replacement qua sign replacement (or qua replacement of signifiers) can be found, for instance, in a definition of translation by Lawrence Venuti (1995: 17) as a process in which a chain of signifiers in an original text in one language is replaced by a chain of signifiers in another language. Replacement has been, however, used earlier and in a more general sense by J. C. Catford when he defined translation to entail "the replacement of textual material in one language (SL) by equivalent textual 
material in another language (TL)" (Catford 1965: 20, 48-49), with equivalence requiring interchangeability in a given situation and the relation of the target language meanings to source language meanings involving substitution. ${ }^{7}$

However, this proposal that translation is a textual replacement, written or spoken, can also be taken literally, and thus not interpreted in the precisely original Catfordian sense. The idea of replacement in the sense that a translation factually takes the place of its original could be applied to the translations of certain multimodal genres, such as picture books and comics. But this literal interpretation of the proposal is highly apparent and concrete as well as physically inseparable in form in certain types of audiovisual translation, such as dubbing and narration. ${ }^{8}$ In these types of translation, whole texts and discourses are, in a word, replaced.

\section{Multimedial intersemioses}

As a matter of fact, audiovisual translation offers an apposite field for practising the laboratory approach to both translation studies and translation semiotics. The multimedia material provides a specific expression for a whole spectrum of sign systems and semiotic manifestations. These range from diverse characteristics that are multimodal, multisemiotic, and multisystemic as well as inter-

\footnotetext{
7 This idea of translation as a replacement or a substitution appears to live within translation studies. In a short introduction to translation, Juliane House (2009) repeats the notion that translation is "the replacement of an original text with another text" (p. 3), "the process of replacing an original text, known as the source text, with a substitute one, known as the target text", or "a process of replacing a text in one language by a text in another" ( $p$. 4). Even when it comes to the Jakobsonian three types of translation, the common denominator appears to be replacement, "the replacement of one expression of a message or unit of meaningful content by another in a different form" (p. 4).

While to represent, to lie, to substitute, and to replace express, in our translational context, the same type of activity, these expressions might not, however, be mutually interchangeable. The first two perhaps have a rather sign-theoretical origin, the last two a rather translation-theoretical anchorage.

8 The main types of audiovisual translation are subtitling and revoicing, the latter consisting of dubbing, narration, and voice-over. In narration, the source-language narration text in a documentary programme is translated and edited and then read by a target-language narrator. Special attention is paid to synchrony and timing. Furthermore, the source language narration in the soundtrack of the original production is replaced by the new target language narration.
} 
semiotic and intersemiosic to the resultant translational constraints. Different modes, codes, and channels create different problems and some of these can be reduced to mere technical questions. Nonetheless, the translator works with the verbal, yet the verbal both interacts with and is dependent on the visual and the aural. All these have their own specific messages to convey. These messages then hopefully intersect and interact and, through integration, create an intersemiosically signifying universe of interpretation - an intersemiosic space.

Subtitling includes particular verbal and visual challenges, as well as temporal and spatial constraints. Subtitling also entails not only interlingual transfer, but transition from the spoken mode to the written, with both modes being simultaneously accessible to the audience. By contrast, dubbing requires synchronization and transition from one language to another; still, the mode remains spoken as is the case with narration. However, in narration, the dialogue parts in an otherwise narrated programme can be rendered by subtitles. In both dubbing and narration, the viewers do not have access to the original dialogue or to the original narration since it has been replaced. ${ }^{9}$

In the translated version of a narrated programme, the visual and the nonreplaced aural parts (in Finland, the tracks with dialogue, sound effects, and music) remain as they are in the original production, and only the narration is replaced. This is a fact that somehow highlights the complementary nature and role of this textual material (on the complexity of the notion of text, including the notion of a complementary text, see Torop 2008a: 234-235).

9 Within the field of Finnish audiovisual translation, the grand old man is Esko Vertanen from the Finnish Broadcasting Company (YLE). In Vertanen's numerous lectures to potential TV-translators, he paid attention to how the programme conventions may differ, noting that something that is natural and expected in one culture can be disturbing in another. For instance, an animal can be personified in a nature documentary, but the Finnish audience considers that solution to be childish. Whereas the original has not evoked a negative reaction, the translation should not do that either. According to Vertanen's experience, this situation can give rise to substantial changes in the translation employed in narration (cf. Saarikoski's above-mentioned view of passages that cannot possibly interest the audience). The question Vertanen poses is whether changes can actually be made, to what extent, and on what grounds.

Translating includes problem-solving and decision-making which reflect the translator's sense and degree of responsibility. The question of what a translator is allowed to do is ultimately a question of ethics, professionalism, and trustworthiness and, furthermore, of copyright regulations. One of the objectives of the present article is to provide a semeioticderived theoretical approach to the problem of how to argue for these types of translatorial interventions. 
From the point of view of a new audience, subtitles could be considered to promote the reception of the multimedial original by complementing it in a mediated and condensed way. By comparison, narration both in the original and in its translation aims at complementing the visual and the aural and does this more directly. The narrated textual passages in the original and in the translated version act like captions. Demonstrating the indexicality involved, they offer us information on how to read the visual, the image. Roland Barthes (1915-1980) uses the term anchorage for this type of a text-image link that diminishes both the interpreter's choice and the inherent polysemy of images and consequently controls and directs interpretation. Moreover, as syntagmatic fragments, text and image can complement each other, the text acting as a relay, "by setting out, in the sequence of messages, meanings that are not to be found in the image itself" (Barthes 1985[1977]: 197-198).

The issue of interpretation-directing choices is interesting since as to interlingual translation, on the one hand, it can refer to the choices made when translating, but on the other hand, it can even refer to producing the original. In both cases, the question concerns selecting representations. These representations can be 'the same' but they can also differ in terms of strategies. If we examine the issue from more a translation-theory-centred perspective, the strategies are semantic, syntactic, and pragmatic. When our approach is more semiotics-centred, however, they are paradigmatic and syntagmatic.

\section{Signs in growth, or anything goes!}

The freedom of choice in audiovisual translation seems to be taken to the extreme in the following quotation. In this passage, we might perceive a less serious tone, yet a realistic attitude towards the translating of multimedial material as well. We might also witness a reflection of the practices and attitudes at different times and places:

"To all these questions ... the synchronization specialists respond that anything goes that makes the point ... And the point is considered made if the audience reacts to the synchronized film in the same way that the audience reacted to the original film, even if it involves fresh inspiration.” Mounin's statement here about film synchronization may be expanded to apply to all forms of audio-medial texts. (Reiss 2000: 46, fn.70; emphases and omissions in original; the quotation is a translation of Georges Mounin, Die Übersetzung: Geschichte, Theorie, Anwendung, p. 145 [Nymphenburger 1967]) 
This quotation emphasizes the deep-rooted translation-theoretical notion of 'equivalent response' (see Nida; Taber 1982[1969]: 24), including a functionalist explanation which suggests the possible strategy of creative translating. Here creation is associated with freedom and "fresh inspiration", but creation can also suggest knowledge creation and consequently, the growth of knowledge through the growth of signs.

The concept of growth is relevant and particularly conspicuous in documentaries because they can provide the viewers with new information and an opportunity to learn. If a nature documentary deals with polar bears, lions, or kangaroos, the novelty value cannot currently be expected to be very high. However, if the programme presents Irukandji, a diminutive and extremely dangerous box jellyfish which is not particularly well-known even to scientists, ${ }^{10}$ the viewers can concretely experience what Peirce meant when he stated, for instance, that symbols grow (CP 2.302, c. 1895), that the sign becomes, when translated, "more fully developed" (CP 5.594, 1903), or that "a sign is something by knowing which we know something more" (CP $8.332=$ PW: 31-32, 1904).

At first glance, the principle of 'anything goes' may appear to be highly provocative and an indication and promise of translatorial empowerment. Yet the continuation, 'that makes the point', illustrates that the translator is not given a free hand, but is bound by what in the above citation is described as sameness of reactions. We can, nevertheless, take this proposal seriously, as we have done in the preceding sections of this article, and in addition, literally. This means that we can examine this proposal and its truthfulness and applicability in more detail to provide it with a semiotic foundation. While doing this, we attempt to resume the ideas that run through the present article: revisiting and thought experiments; translation, semiotic views of translation, and sign translation; as well as representation, mediation, and selection.

The notion of selection now receives a new interpretation. I mentioned earlier that the author of the original and the translator of this original select representations. Nevertheless, a Peircean approach to sign translation introduces a novel, primary actor that must be taken into account. This actor is the catalyst for both sign action and sign interpretation, in short, for every semiosis - the object of the sign.

10 An example of a documentary on Irukandji is Killer Jellyfish (2006). I participated in the translation/editing of the Finnish version, Tappajameduusa - Killer Jellyfish, in 2007. 
According to the Peircean conception of the sign, a sign is "anything which on the one hand is so determined by an Object and on the other hand so determines an idea in a person's mind, that this latter determination, $[\ldots]$ the Interpretant of the sign, is thereby mediately determined by that Object" (CP 8.343, 1908; emphasis in original). In this unlimited process of mediation and determination, the sign, or actually a sign-vehicle or a representamen, is generated and specified by the object. This suggests that the sign turns into a mediator working for its two-sided object. Of these, the immediate object is not central, since it is only what the imprecise sign appears to represent, refer to and tell about, "the Object as the Sign represents it" (CP 8.343, 1908; see also, PW: 196, 1906). Therefore, the immediate object does not constitute the reality behind the sign, yet it is information on this reality that any translationoriented sign analysis ought to attain. However, this reality is not totally unapproachable but is accessible in the other object, the "really efficient but not immediately present" dynamical object (CP 8.343, 1908), which cannot be translated but which can be referred to mediatedly by new signs, interpretants, or a series of interpretants.

In any case, it is the object that matters most: the object "is the semeiotic cause", "the cause of the sign", that is to say, a real context and situation the significance of which needs a sign and is conveyed by this sign (Savan 1994: 73-74; his emphasis). And as David Savan (1916-1992) argues, drawing on Peirce, this significance could be transmitted by a range of diverse signs: “[ [... each interpretant is itself a further sign, and hence a translation of an earlier sign. It is essential not only to language but to all signs that they be translatable, and that what any one sign stands for, an indefinite variety of other signs may also stand for" (Savan 1987-88: 17; my emphasis). Thus, not any sign but, and this is translation-theoretically crucial, not merely those signs that have initially been chosen, on the contrary, "an indefinite variety of other signs". Savan's observation crystallizes the problem of translation, when expanded to concern both the primary sign, or the original text, and the secondary sign, the translation. At the same time, this observation also indicates what makes translating in its intralingual, interlingual, and intersemiotic forms possible.

This semeiotic perspective introduces a relative and realistic view of translation. Here the emcployed sign-vehicle, which represents the object, could be some other sign-vehicle as well. In this view, it is the object that has a free hand and is independent, when it "addresses somebody, that is, creates in the mind of that person an equivalent sign, or perhaps a more developed sign" 
(CP 2.228, c. 1897). Nonetheless, if we pose the earlier question concerning what can be used for representing, lying, substituting, or replacing (in actions also known as translating), we can conclude that the answer is: almost any sign. Yet precisely how the translator is involved here remains unclear. Even so, Peirce appears to provide the translator with a role, actually not as a mind that is translating and interpreting actively, but as someone who is addressed by a sign and who lets his or her mind be addressed.

The message to the author of the original is "Almost anything goes", but this is also the message to the translator, even when the former has made his or her choices. In interlingual translation, it has not been the word (letter) that is crucial but the sense (spirit). In the same way, according to Peircean sign translation and perhaps paradoxically, it is not the (originally chosen) sign as such that is central, but the object and cause of the sign: it is the causes that are to be transmitted. This suggests that there are several ways to refer, for instance, to the above-mentioned Irukandji such that this Irukandji, as a real object (and as a sign as well), "may gain more significance, more meaning, may be better understood, may yield more information" (Savan 1994: 73). Furthermore, this also constitutes the semeiotic argument for translatorial interventions (solutions that promote the semeiotic cause of the sign) and makes any otherwise radical solution less radical. And when the object has found a signifying manifestation, the task of the sign as a mediator and translator is completed, at least temporarily.

\section{New translations}

The present article has probed, to some extent, the limits of translation by studying what is obvious through Peirce-inspired thought experiments. Because thoughts are signs (CP 5.594, 1903), the life of thoughts is a life of signs. And it is this life of signs that semioticians are interested in.

When Peirce scholarship is interested in signs, it focuses, in fact, on translations. Semeiotically, this is self-evident, because the prerequisites for signhood are to represent and to be able to create an interpretation and an interpretant - representability and interpretability/translatability, and sometimes even that of actually being interpreted and translated. Just as symbols can grow, so can thoughts and theoretical constructions, "in incessant new and higher translations" (ibid.). This is what renders revisiting inquiry necessary. 


\section{References}

Baker, Mona 1998. Introduction. In: Baker, Mona (ed.), Routledge Encyclopedia of Translation Studies. London: Routledge, xiii-xviii. [Paperback edition 2001.]

Barthes, Roland 1985[1977]. Rhetoric of the image. In: Innis, Robert E. (ed.), Semiotics: An Introductory Anthology. London: Hutchinson, 192-205.

Bassnett, Susan 1991[1980]. Translation Studies. (New Accents.) Revised edition. London: Routledge.

Catford, J. C. 1965. A Linguistic Theory of Translation: An Essay in Applied Linguistics. (Language and Language Learning.) Oxford: Oxford University Press. [Sixth impression 1980.]

Chesterman, Andrew 2003. Does translation theory exist? Kääntäjä - Översättaren 6/2003, 4. Available at: http://www.helsinki.fi/ chesterm/2003c.exist.html [accessed 5.6.2012].

CP $=$ Peirce, Charles Sanders 1931-1958.

Eco, Umberto 1979[1976]. A Theory of Semiotics. (Advances in Semiotics.) Bloomington: Indiana University Press.

Gambier, Yves 2009. Challenges in research on audiovisual translation. In: Pym, Anthony; Perekrestenko, Alexander (eds.), Translation Research Projects 2. Tarragona: Intercultural Studies Group, 17-25.

Hartama-Heinonen, Ritva 2008. Abductive Translation Studies: The Art of Marshalling Signs. (Acta Semiotica Fennica 28.) Imatra: International Semiotics Institute.

- 2009. Kääntäminen valehtelemisena [To translate is to lie]. In: Hekkanen, Raila; Kumpulainen, Minna; Probirskaja, Svetlana (eds.), MikaEL - Kääntämisen ja tulkkauksen tutkimuksen symposiumin verkkojulkaisu - Electronic proceedings of the KäTu symposium on translation and interpreting studies, Vol. 3. Helsinki: Suomen kääntäjien ja tulkkien liitto, 1-9.

Hermans, Theo 2006. Foreword. In: Loffredo, Eugenia; Perteghella, Manuela (eds.), Translation and Creativity: Perspectives on Creative Writing and Translation Studies. London: Continuum, ix-x.

Hjelmslev, Louis 1969[1961]. Prolegomena to a Theory of Language. (Whitfield, Francis J., trans.) Revised English edition. Madison: The University of Wisconsin Press.

House, Juliane 2009. Translation. (Oxford Introductions to Language Study.) Oxford: Oxford University Press.

Huetius, Petrus Danielus 1992[1683]. Extract from De optimo genere interpretandi (Two books on translation). (Lefevere, André, trans.) In: Lefevere, André (ed.), Translation/History/Culture: A Sourcebook. (Translation Studies). London: Routledge, 86-102.

Jakobson, Roman 1966[1959]. On linguistic aspects of translation. In: Brower, Reuben A. (ed.), On Translation. New York: Oxford University Press, 232-239.

Klemola, Timo 2004. Taidon filosofia - Filosofin taito [The philosophy of art: The art of the philosopher]. Tampere: Tampere University Press. 
Lefevere, André 1992. Introduction. In: Lefevere, André (ed.), Translation/History/ Culture: A Sourcebook. (Translation Studies). London: Routledge, 1-10.

Lotman, Yuri M. 1990. Universe of the Mind: A Semiotic Theory of Culture. (Shukman, Ann, trans.) London: I. B. Tauris.

Newmark, Peter 1993. Paragraphs on Translation. Clevedon: Multilingual Matters.

Nida, Eugene A.; Taber, Charles R. 1982[1969]. The Theory and Practice of Translation. (Helps for Translators: Prepared under the Auspices of the United Bible Societies, volume 8.) Second photomechanical reprint. Leiden: E. J. Brill.

Peirce, Charles S. 1931-1958. Collected Papers of Charles Sanders Peirce. Cambridge: Harvard University Press. [Hartshorne, Charles; Weiss, Paul (eds.), 1931-1935; vols. 7-8. Burks, A. W. (ed.) 1958; In-text references are to CP, followed by volume and paragraph numbers and year of writing]

Petrilli, Susan 2001. Translation. In: Cobley, Paul (ed.), The Routledge Companion to Semiotics and Linguistics. London: Routledge, 278-279.

PW = Semiotic and Significs: The Correspondence between Charles S. Peirce and Victoria Lady Welby 1977. Bloomington: Indiana University Press. [Ed. by Charles S. Hardwick with the assistance of James Cook; in-text references are to PW, followed by page number(s)]

Reiss, Katharina 2000. Translation Criticism - the Potentials and Limitations: Categories and Criteria for Translation Quality Assessment. (Rhodes, Erroll F., trans.) Manchester: St. Jerome Publishing.

Remael, Aline 2010. Audiovisual translation. In: Gambier, Yves; van Doorslaer, Luc (eds.), Handbook of Translation Studies. Volume 1. Amsterdam: John Benjamins Publishing Company, 12-17.

Savan, David 1987-1988. An Introduction to C. S. Peirce's Full System of Semeiotic. (Monograph Series of the Toronto Semiotic Circle Number 1.) Toronto: Victoria College in the University of Toronto.

- 1994. Letter from David Savan to Jean Fisette 8 April '91. [Appendix B in Jean Fisette's article Le représentamen, le fondement, le signe et l'abduction.] In: Shapiro, Michael (ed.), The Peirce Seminar Papers: An Annual of Semiotic Analysis. Volume 2. Providence: Berghahn Books, 71-77.

Sütiste, Elin 2008. Roman Jakobson and the topic of translation: Reception in academic reference works. Sign Systems Studies 36(2): 271-314.

Tappajameduusa (Killer Jellyfish). A documentary programme sent in Tiedeohjelma Prisma, The Finnish Broadcasting Company (YLE), TV1 20.8.2007. Finnish realisation: Hartama, Marko; Hartama-Heinonen, Ritva; Rajalin, Juhani. A Digital Dimensions/Parthenon Production for Animal Planet International. Parthenon Entertainment Ltd. 2006.

Torop, Peeter 2000. Intersemiosis and intersemiotic translation. $S$ - European Journal for Semiotic Studies 12(1): 71-100.

- 2001. Coexistence of semiotics and translation studies. In: Kukkonen, Pirjo; HartamaHeinonen, Ritva (eds.), Mission, Vision, Strategies, and Values: A Celebration of 
Translator Training and Translation Studies in Kouvola. Helsinki: Helsinki University Press, 211-220.

- 2002. Translation as translating as culture. Sign Systems Studies 30(2): 593-605.

- 2008a. Identity of cultural texts and creolization of cultural languages. In: Hatten, Robert S.; Kukkonen, Pirjo; Littlefield, Richard; Veivo, Harri; Vierimaa, Irma (eds.), A Sounding of Signs: Modalities and Moments in Music, Culture, and Philosophy. Essays in Honor of Eero Tarasti on his $60^{\text {th }}$ Anniversary. (Acta Semiotica Fennica 30.) Imatra: International Semiotics Institute at Imatra, 223-236.

- 2008b. Translation and semiotics. Sign Systems Studies 36(2): 253-257.

- 2008c. Translation as communication and auto-communication. Sign Systems Studies 36(2), 375-397.

Venuti, Lawrence 1995. The Translator's Invisibility: A History of Translation. (Translation Studies.) London: Routledge.

Williams, Jenny; Chesterman, Andrew 2002. The Map: A Beginner's Guide to Doing Research in Translation Studies. Manchester: St. Jerome Publishing.

\section{Новый взгляд на переводо-семио-теоретические отголоски}

Статья рассматривает процесс перевода и сами переводы прежде всего с сем(е)иотической точки зрения, фокусируясь, с одной стороны, на семиотическом перечитывании определенных понятий теории перевода (напр., понимание перевода как исконно семиотической категории), с Аругой - на перечитывании с точки зрения теории перевода некоторых семиотических установок (например, какого типа знаки можно использовать Аля репрезентации). СреАи разных пересматриваемых концепций находятся и типология перевода Романа Якобсона, и определение Умберто Эко семиотики как теории мжи. ПодхоА, принятый в настоящей статье, призывает к серьезному перечитыванию и отношению к тексту, Ааже к буквальному прочтению, но временами и не к столь серьезному отношению к нему.

\section{Uus pilguheit tõlke-semiootilis-teoreetilistele järelkajadele}

Artikkel käsitleb tõlkimist ja tõlkeid eeskätt sem(e)iootilisest vaatepunktist. Fookus on ühelt poolt teatud tõlketeoreetiliste arusaamade (nagu ettekujutus tõlkest kui olemuslikult semiootilisest kategooriast) semiootilisel ülelugemisel ja teiselt poolt teatud semiootiliste arusaamade (nagu mis laadi märke saab kasutada representeerimiseks) tõlketeoreetilisel ülelugemisel. Teiste kontseptsioonide seas, mida samuti värske pilguga vaagitakse, on Roman Jakobsoni tõlketüpoloogia ja Umberto Eco käsitus semiootikast kui valeteooriast. Käesolevas artiklis kasutatud lähenemine propageerib tõsist ülelugemist ja suhtumist, kuid enamgi veel, sõnasõnalist lugemist, ja vahetevahel ka vähem tõsist suhtumist. 